\title{
The use of the radial artery as the second choice for arterial graft in patients over 70 years of age
}

\author{
Utilização da artéria radial como segundo enxerto arterial em pacientes acima de 70 anos
}

Joseph Fredric WHITAKER, Pedro Horácio Cosenza PASSOS, Gustavo de Moraes RAMALHO, Antônio José MUNIZ, Rogério de Castro PIMENTEL, João Batista Lopes LOURES, Ângela de Fátima BORGES, Antônio Augusto MIANA

RBCCV 44205-730

\section{Abstract}

Objective: Retrospective study evaluating the morbidmortality and hospital behavior in over 70 -year-old patients submitted to myocardial revascularization involving the radial artery as the second arterial graft.

Method: During the period of August 1994 to December 2002, 2487 cases of myocardial revascularization were performed by the group of the Juiz de Fora Heart Institute, 476 of whom were 70 years of age or older and 36 (Group II) received the radial artery as the second arterial graft. The same type of surgery was performed in 142 under 70 -year-old patients (Group I). Reoperations, off-pump operations (OPCAB) or associated procedures were excluded from this study.

Results: The median age was 72.5 years, the mortality rate was $6 \%$ in this group of patients and the incidence of complications was low, comparable to the 142 under 70-yearold patients (Group I) submitted to the same type of surgery.

Conclusion: The results achieved with this study lead the authors to believe that the radial artery can be safely used as the second arterial graft in well selected septuagenarian patients, despite the greater risk of co-morbidities related to this age group.

Descriptors: Coronary artery disease, surgery. Radial artery. Myocardial revascularization, old age.

\section{Resumo}

Objetivo: Estudo retrospectivo para avaliar a morbimortalidade e a evolução hospitalar em pacientes com idade superior a 70 anos, submetidos à operação de revascularização do miocárdio com utilização da artéria radial como segundo enxerto arterial.

Método: No período de agosto de 1994 a dezembro de 2002, foram realizadas 2487 cirurgias de revascularização do miocárdio no Instituto do Coração de Juiz de Fora. Dentre os pacientes operados, 476 tinham idade superior a 70 anos, sendo que em 36 (Grupo II) foi utilizada a artéria radial como $2^{\circ}$ enxerto arterial. $O$ mesmo tipo de cirurgia foi realizado em 142 pacientes com idade inferior a 70 anos (Grupo I). Não foram incluídas neste estudo reoperações, cirurgias sem CEC ou com procedimentos associados.

Work performed by the team of the Heart Surgery Department of the Instituto do Coração de Juiz de Fora, in the Santa Casa de Misericórdia hospital in Juiz de Fora and Hospital and Maternidade Monte Sinai. 
Resultados: A média de idade do Grupo II foi 72,5 anos, a mortalidade hospitalar neste grupo de pacientes foi $6,0 \%$, a incidência de complicações também foi baixa, comparável à observada no mesmo tipo de operação realizada em pacientes com idade inferior a 70 anos.

Conclusão: Diante destes resultados, os autores acreditam

\section{INTRODUCTION}

Demographic data in Brazil and in developed countries indicate an evident increase in the population of the elderly. Estimates place Brazil as the country that will have the sixth highest number of elderly in the world in 2025 [1].

Sources from the Brazilian Government Census Department demonstrate a life expectancy of around 67.6 years today. Data from the USA reveal a life expectancy for those who reach 65 years, of 15.6 years and this is increasing [2].

The incidence of atherosclerotic disease in these patients is known to be high with an elevated rate of multiarterial involvement and complex lesions with rigid and tortuous arteries. In these cases, surgery is the most attractive alternative, in spite of the development of interventionist treatment [2-4].

The advances in the surgical technique, types of oxygenators, myocardial protection, a greater utilization of off-pump surgery, intensive care management and better preoperative and postoperative physiotherapy contribute to an attractive reduction of the morbid-mortality rate in this special group of patients.

The use of the left internal thoracic artery is already consolidated in this group of patients $[3,5,6]$ due to its better patency. The use of both internal thoracic arteries is correlated to a greater number of sternal complications; venous grafts are still widely utilized but are known to present with a high occlusion rate, specifically after the fifth post-operative year [7]. So, why not use a second arterial graft, wherever possible, in this group of patients to try to avoid the possibility of reoperation?

The results of ACAR et al. [8] and CALAFIORE et al.[11] suggest the use of the radial artery as a second option of arterial graft in over 70-year-old patients that are in good physical shape and have compatible coronary angiographic results.

\section{Surgical technique}

All patients were approached by medium sternotomy. Simultaneously the radial artery was carefully dissected with as little manipulation as possible. In this group of patients a membrane oxygenator and centrifuge pump was used, with systemic heparinization $(4 \mathrm{mg} / \mathrm{kg})$, moderate hypothermia, careful manipulation of the aorta with a single period of que a artéria radial possa ser usada com segurança como $2^{\circ}$ enxerto arterial em pacientes acima de 70 anos, criteriosamente selecionados, apesar do maior risco de comorbidades associadas nesta faixa etária.

Descritores: Coronariopatia, cirurgia. Artéria radial. Revascularização miocárdica, idoso.

clamping using a protected clamp when necessary in order to avoid fragmentation of plaque and venous drainage using a single two-stage catheter. Myocardial protection was achieved by intermittent anterograde hypothermic blood cardioplegia. In all patients, the Allen test was made in the preoperative period using Doppler when necessary and a pulse oximeter. Endovenous diltiazem was utilized for the induction of anesthesia and continuous nitroglycerin infusion was maintained in the perioperative period and in the ICU. Until its utilization, the artery was maintained immersed in a solution of diltiazem, papaverine and xylocain. Topical cooling was avoided when possible when the radial was utilized. The distal anastomoses were performed first Sequential anastomoses with the radial artery were performed when possible and the artery was anastomosed in $\mathrm{Y}$ to the left internal thoracic artery if possible.

\section{RESULTS}

One hundred and forty-two under 70-year-old patients (Group I) and 36 over 70-year-old patients (Group II) received the radial artery as the second arterial graft (Figure 1).

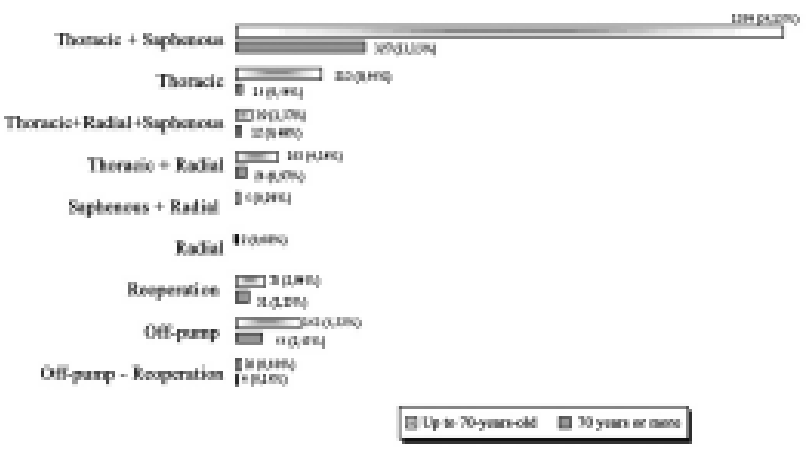

Fig. 1 - Type of operation x age range from August 1994 to December 2002

* Patients selected for the study

Two in-hospital deaths occurred both in Group II. One of them was due to spasms of the radial artery refractory to medication, progressing to low output. The patient was submitted to reoperation to replace the arterial graft for a 
venous graft but continued with low output and died on the fourth postoperative day. The other patient had associated dilated heart disease and evolved with low output and respiratory failure and died on the 60th postoperative day. Both received mechanic support (intra-aortic balloon).

The percentage of patients with left coronary trunk injury in Group II was $27.7 \%$ (10 patients). There was no necessity to review hemostasis in this group.

Table 1. Comparative analysis of the complications in patients submitted to the same type of operation by age range: $<70$ years (Group I) and $=70$ years (Group II).

\begin{tabular}{|c|c|c|c|}
\hline \multirow[b]{2}{*}{$\begin{array}{l}\text { Main types } \\
\text { of complications }\end{array}$} & \multicolumn{2}{|c|}{ Age range } & \multirow[b]{2}{*}{$\mathrm{p}^{*}$} \\
\hline & $\begin{array}{l}\text { Group I } \\
\text { under } 70 \text { years } \\
(n=142)\end{array}$ & $\begin{array}{l}\text { Group II } \\
70 \text { years } \\
\text { or more } \\
(n=36)\end{array}$ & \\
\hline Low heart output syndrome & $6(4.2 \%)$ & $2(5.6 \%)$ & 1.000 \\
\hline Stroke & $1(0.7 \%)$ & - & 1.000 \\
\hline Coagulation disorders & $2(1.4 \%)$ & - & 1.000 \\
\hline renal insufficiency & $1(0.7 \%)$ & - & 1.000 \\
\hline Respiratory insufficiency & $7(4.9 \%)$ & $3(8.3 \%)$ & 0.425 \\
\hline Mediastinitis & - & - & - \\
\hline
\end{tabular}

Non-significant values $(\mathrm{p}>0.05)$.

Table 2. Most common previous circumstances in the two groups submitted to the same type of surgery.

\begin{tabular}{llll}
\hline \multicolumn{4}{c}{ Age range } \\
$\begin{array}{l}\text { Main types of } \\
\text { previous circumstances }\end{array}$ & $\begin{array}{l}\text { Group I } \\
\text { under } 70 \text { years } \\
(\mathrm{n}=142)\end{array}$ & $\begin{array}{l}\text { Group II } \\
70 \text { years or } \\
\text { more }(\mathrm{n}=36)\end{array}$ & $\mathrm{p}^{*}$ \\
\hline AMI & $37(26.1 \%)$ & $5(13.9 \%)$ & 0.125 \\
SAH & $52(36.6 \%)$ & $21(58.3 \%)$ & $0.018 \dagger$ \\
Diabetes & $30(21.1 \%)$ & $8(22.2 \%)$ & 0.886 \\
Dyslipidemia & $15(10.6 \%)$ & $1(2.8 \%)$ & 0.200 \\
Obesity & $15(10.6 \%)$ & $6(16.7 \%)$ & 0.384 \\
Smoker & $49(34.5 \%)$ & $9(25.0 \%)$ & 0.277 \\
Family history & $33(23.2 \%)$ & $7(19.4 \%)$ & 0.626 \\
COPD & $2(1.4 \%)$ & - & 1.000 \\
Stroke & $4(2.8 \%)$ & - & 0.584 \\
\hline
\end{tabular}

*Non-significant values $(p>0.05) \dagger$ Non-significant values $(p>$ $0.01)$.

AMI - Acute myocardial infarction; SAH - systemic arterial hypertension; COPD - chronic obstructive pulmonary disease.
The mean number of anastomoses per patient in Group II was 3.47 , as seen in Table 3 .

There were no statistical differences between the groups in respect to the main types of complications and prior conditions, as illustrated in Tables 1 and 2 respectively and there was no evidence of significant difference between the studied groups $\mathrm{n}$ relation to death (Table 4).

Table 3. Mean number of anastomoses by age range.

\begin{tabular}{llll}
\hline \multicolumn{4}{c}{ Age range } \\
Type of Operation & $\begin{array}{l}\text { Group I } \\
\text { under 70 years }\end{array}$ & $\begin{array}{l}\text { Group II } \\
70 \text { years or } \\
\text { more }\end{array}$ & Total \\
\hline $\begin{array}{l}\text { Thoracic+Radial } \\
\text { Thoracic+Saphenous } \\
\text { +Radial }\end{array}$ & 2.87 & 3.17 & 2.93 \\
Total & 4.23 & 4.08 & 4.19 \\
\hline
\end{tabular}

Table 4. Percentage of deaths by age range restricted to operations involving the radial artery as the second artery.

\begin{tabular}{lllll}
\hline \multicolumn{5}{c}{ Age range } \\
$\begin{array}{l}\text { Hospital } \\
\text { Mortality }\end{array}$ & $\begin{array}{l}\text { Group I } \\
\text { under 70 years }\end{array}$ & $\begin{array}{l}\text { Group II } \\
70 \text { years or } \\
\text { more }\end{array}$ & Total & $\mathrm{p}^{*}$ \\
& & & \\
\hline No & $132(93 \%)$ & $34(94 \%)$ & $166(93 \%)$ \\
Yes & $10(7 \%)$ & $2(6 \%)$ & $12(7 \%)$ & 1.000 \\
Total & $142(100 \%)$ & $36(100 \%)$ & $178(100 \%)$ \\
\hline
\end{tabular}

* Non-significant values $(\mathrm{p}>0.05)$.

Statistic analysis was achieved using the statistics program SPSS v.11.01 (Statistical Package for Social Sciences). To determine associations among the main types of complications, antecedents and deaths within the groups, the Qui-square test (for expected rates of more than five) and Fisher exact test (for $2 \times 2$ tables and expected frequencies of less than five) were utilized. The adopted level of significance was $5 \%$.

\section{COMMENTS}

The increase in the life expectancy of our population is 
very clear, with an evident increase in the number of over 70 -year-olds $[1,4]$

The incidence of atherosclerotic disease in this population is known to be high $[1,4]$ and the benefits of coronary artery bypass grafting have already been extensively demonstrated. [2-4,10]. The utilization of the left internal thoracic artery to the anterior intraventricular branch (with all its benefits) has already been proven [57], including its utilization in over 70 -year-old patients. The use of arterial grafts has been the primary goal of all services, trying to reduce the reoperation and cardiovascular event rates [8,9,11-13]. In spite of the great applicability of the saphenous graft, it is known that its evolution over the mid term and long term is unsatisfactory $[6,11,14,15]$. So why not use the same type of graft utilized in young patients in selected elderly patients?

It is known that the use of two internal thoracic arteries in elderly patients is a problem due to devitalized bone and diabetes, frequently occurring together, which cause a greater incidence of mediastinitis $[9,14]$. The approach of the gastroepiploic artery is also problematic because of the involvement of the abdominal cavity and by the anatomic limitation of its utilization.

The use of radial artery appears to be a logical option, due to its easy management, graft duplicity, the possibility of sequential anastomoses and elimination of aortic handling [16-18].

Due to advances in interventionist treatment, surgery is left to cases involving multiple arteries and trunk lesions, with the results being continuously.

We believe that with careful selection of this type of patient, taking into account the coronary anatomy, physical state of the patient, the quality of the radial arteries and the presence or not of atherosclerotic plaque, we can safely opt to use the radial artery.

There is no increase in the operative time, there is no more bleeding, low output or mortality by its utilization as has already been demonstrated [13,17].

The patient seems to walk earlier with a fewer number of complications when there is no manipulation of lower limbs [17].

Indeed, this work was concerned only about evaluating the utilization of the radial artery as the second arterial graft in the elderly who have physical conditions and an appropriate coronary anatomy, because of the benefits this conduct provides to a group of patients where reoperation is highly undesirable.

Protocols with late coronary angiographic studies would be advantageous, however, the characteristics of our service make in this type of control difficult.

\section{CONCLUSION}

The utilization of the radial artery as the second arterial graft in coronary artery bypass grafting in over 70-year-old patients seems to be safe and presents good immediate results. The patients, nevertheless, must be carefully selected.

\section{BIBLIOGRAPHIC REFERENCES}

1. Deininger MO, Oliveira OG, Guedes MGA, Deininger EG, Cavalcanti ACW, Cavalcanti MGFW et al. Cirurgia de revascularização do miocárdio no idoso: estudo descritivo de 144 casos. Rev Bras Cir Cardiovasc. 1999;14(2):88-97.

2. Loop FD, Lytle BW, Cosgrove DM, Goormastic M, Taylor $\mathrm{PC}$, Golding LA et al. Coronary artery bypass graft surgery in the elderly: indications and outcome. Cleve Clin J Med. 1988;55(1):23-34

3. Busch T, Friedrich M, Sirbu H, Stamm C, Zenker D, Dalichau $\mathrm{H}$. Coronary artery bypass procedures in septuagenarians are justified: short and long-term results. J Cardiovasc Surg. 1999;40(1):83-91.

4. Loures DRR, Carvalho RG, Mulinari L, Silva Jr AZ, Schmidlin $\mathrm{CA}$, Brommelstroet $\mathrm{M}$ et al. Cirurgia cardíaca no idoso. Rev Bras Cir Cardiovasc. 2000;15(1):1-5.

5. Gardner TJ, Greene PS, Rykiel MF, Baumgartner WA Cameron DE, Casale AS et al. Routine use of the left interna mammary artery graft in the elderly. Ann Thorac Surg. 1990;49(2):188-94

6. Tyszka AL, Fucuda LS. O uso da artéria torácica interna no idoso: indicações e resultados imediatos. Rev Bras Cir Cardiovasc. 2001;16(4):269-74.

7. Loop FD, Lytle BW, Cosgrove DM, Stewart RW, Goormastic $\mathrm{M}$, Williams GW et al. Influence of the internal-mammaryartery graft on 10-year survival and other cardiac events. N Engl J Med. 1986;314(1):1-6.

8. Acar C, Jebara VA, Portoghese M, Beysen B, Pagny JY, Grare $P$ et al. Revival of the radial artery for coronary artery bypass grafting. Ann Thorac Surg. 1992;54(4):652-60. 
9. Calafiore AM, Di Giammarco G, Teodori G, D’Annunzio E, Vitolla G, Fino $\mathrm{C}$ et al. Radial artery and inferior epigastric artery in composite grafts: improved midterm angiographic results. Ann Thorac Surg. 1995;60(3):517-24.

10. Iglezias JCR, Oliveira Jr. JL, Fels KW, Dallan LA, Stolf NAG, Oliveira SA et al. Fatores prognósticos na revascularização do miocárdio em pacientes idosos. Rev Bras Cir Cardiovasc. 1997;12(4):325-34.

11. Barlem AB, Saadi EK, Gib MC, Manfroi WC. Enxertos arteriais na cirurgia de revascularização do miocárdio: papel da artéria radial. Rev Bras Cir Cardiovasc. 2001;16(1):53-7.

12. Sperti G, Manasse E, Kol A, Canosa C, Grego S, Milci C et al. Comparison of response to serotonin of radial artery grafts and internal mammary grafts to native coronary arteries and the effect of diltiazem. Am J Cardiol. 1999;83(4):592-6.

13. Lisboa LAF, Dallan LAO, Puig LB, Abreu Filho C, Leca RC, Dallan LAP et al. Seguimento clinico a médio prazo com uso exclusivo de enxertos arteriais na revascularização completa do miocárdio em pacientes com doença coronária triarterial. Rev Bras Cir Cardiovasc. 2004;19(1):9-16.
14. Rabelo RC, Reis Filho FAR, Bernardes RC, Motta GG, Lima LCM, Gonçalves LAA et al. Revascularização completa do miocárdio: pontes seqüenciais de veia safena, anastomoses seqüenciais da artéria torácica interna e enxertos compostos: análise de 165 casos consecutivos. Rev Bras Cir Cardiovasc. 1997;12(2):110-4.

15. Paniagua PR, Rezende MC, Carranza RB, Gomes CRM, Sabatovicz Jr N, Marques DLL et al. Cirurgia de revascularização do miocárdio com enxertos compostos. Rev Bras Cir Cardiovasc. 1999;14(1):14-8.

16. Acar C, Ramsheyi A, Pagny JY, Jebara V, Barrier P, Fabini JN et al. The radial artery for coronary artery bypass grafting: clinical and angiographic results at five years. J Thorac Cardiovasc Surg. 1998;116(6):981-9.

17. Brodman RF, Frame R, Camacho M, Hu E, Chen A, Hollinger I. Routine use of unilateral and bilateral radial arteries for coronary artery bypass graft surgery. J Am Coll Cardiol. 1996;28(4):959-63.

18. Weinschelbaum EE, Gabe ED, Macchia A, Smimmo R, Suarez LD. Total myocardial revascularization with arterial conduits: radial artery combined with internal thoracic arteries. J Thorac Cardiovasc Surg. 1997;114(6):911-6. 